\title{
Approaches to optimize therapeutic bacteriophage and bacteriophage-derived products to combat bacterial infections
}

\author{
Monika Reuter ${ }^{1}\left[\right.$ Detlev H. Kruger ${ }^{1}$
}

Received: 28 May 2019 / Accepted: 18 January 2020 / Published online: 8 February 2020

(c) Springer Science+Business Media, LLC, part of Springer Nature 2020

\begin{abstract}
The emerging occurrence of antibiotic-resistant bacterial pathogens leads to a recollection of bacteriophage as antimicrobial therapeutics. This article presents a short overview of the clinical phage application including their use in military medicine and discusses the genotypic and phenotypic properties of a potential "ideal" therapeutic phage. We describe current efforts to engineer phage for their improved usability in pathogen treatment. In addition, phage can be applied for pathogen detection, selective drug delivery, vaccine development, or food and surface decontamination. Instead of viable phage, (engineered) phage-derived enzymes, such as polysaccharide depolymerases or peptidoglycan-degrading enzymes, are considered as promising therapeutic candidates. Finally, we briefly summarize the use of phage for the detection and treatment of "Category A priority pathogens".
\end{abstract}

Keywords Antibiotic resistance $\cdot$ Biofilms $\cdot$ Category A priority pathogens $\cdot$ Genetic engineering $\cdot$ Military medicine . Phage application $\cdot$ Phage-derived enzymes $\cdot$ Therapeutic phage

\section{Introduction}

The idea to use phage as treatment option for bacterial infections came up immediately after the discovery of bacterial viruses (bacteriophage or phage) one century ago. As early as in the 1920s, an institute for bacteriophage was founded

This review refers to a presentation given by the authors at the 16th Medical Biodefense Conference, Munich, October 28-31, 2018.

We dedicate this paper to Elizabeth Kutter (Olympia, WA.) acknowledging her fundamental contributions to phage research and her efforts in building bridges between scientists in East and West.

Edited by Lothar Zöller.

Monika Reuter

dr.monika.reuter@gmx.net

Detlev H. Kruger

detlev.kruger@charite.de

1 Institute of Virology, Helmut-Ruska-Haus, Charité Universitätsmedizin Berlin, Corporate Member of Freie Universität Berlin, Humboldt-Universität Zu Berlin, and Berlin Institute of Health, Charitéplatz 1, 10117 Berlin, Germany in Tbilisi, Georgia (former Soviet Union). In the following "era of antibiotics", the potential significance of phage as therapeutics became underestimated. Under the pressure of global emergence of antibiotic-resistant bacteria and supply shortages for certain antibiotics, the idea of phage therapy has been revitalized during the last years; many institutions and commercial companies are currently engaged in this field. There are case histories describing successful phage therapy of single patients; however, the number of controlled clinical studies, particularly those demonstrating efficacy to modern standards, is still limited. Besides the treatment of antibiotic-resistant bacterial pathogens, phage can be applied as biological control agents for pathogen detection and identification or for food and surface decontamination. Molecular engineering of phage or phage-derived enzymes could improve its practical use for these applications. Certainly, detection and treatment approaches of Category A priority pathogens will benefit from these developments. Figure 1 summarizes main targets for phage application studied currently.

Antibiotic-resistant bacteria have emerged globally, mainly due to antibiotic overuse and misuse, resulting in increased morbidity rates, mortality rates, and healthcare costs. On reviewing medicinal literature and experts' opinion, Bassetti et al. stated that in the last decade, all attempts 
Fig. 1 Targets of phage application. The figure depicts major routes of phage research followed currently. Illustration in the center (digitally processed aquarelle) shows the universe of bacteria and their natural enemies (courtesy of Petra Mackeldanz)

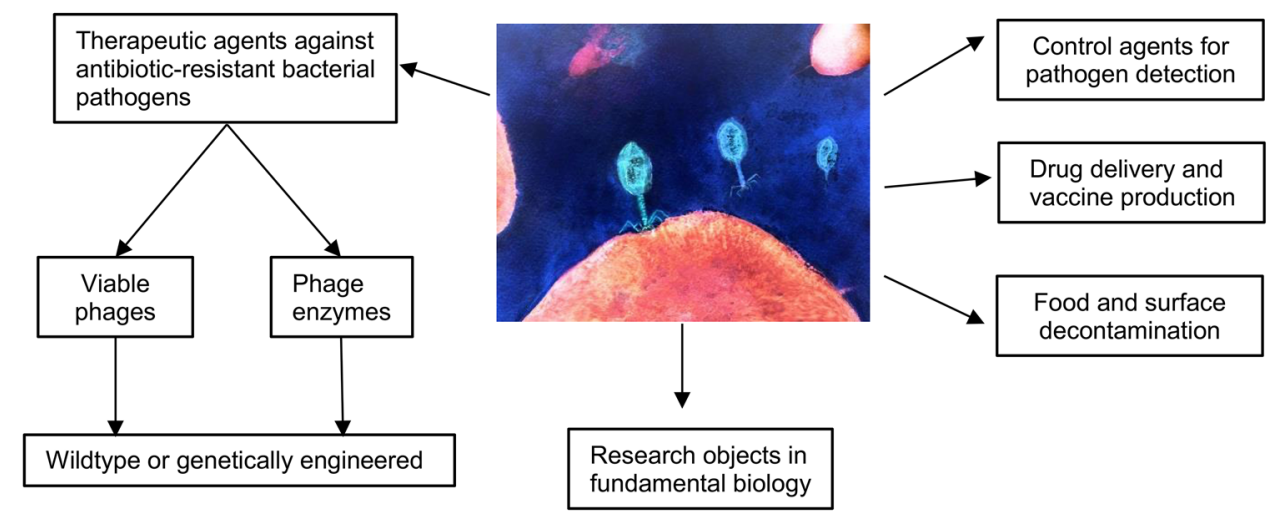

of infection prevention and control were unable to circumvent the rapid spread of resistant bacterial pathogens. The authors estimate that this antibiotic resistance crisis will cause worldwide 10 million deaths per annum in 2050 [1]. Therefore, the work on alternative strategies to reverse this trend and to provide a means to treat these pathogens is indispensable [2-6]. Phage therapy is one promising route.

Bacteriophage are viruses of bacteria and as obligate cellular parasites have mainly two options to interact with the bacterial host: a lytic or a lysogenic growth cycle. During the lytic way, phages use the cellular processes and resources to produce tens to hundreds of progeny phages, which exit the host cell with or without killing. During the lysogenic way, the phage integrates its genome into the bacterial chromosome and is replicated as part of it (in some cases the phage keeps an extrachromosomal form) [7]. Under certain intracellular and/or environmental conditions, this process is reversible and the phage genome can be excised and can switch back to the lytic cycle. These so-called temperate phages can decide in every infection cycle whether to replicate and lyse their host or to lysogenize and keep the host alive.

\section{Clinical use of phage}

\section{Short overview}

Among all scientists more than one century ago who described lytic effects in bacterial colonies, which could have been caused by an agent called bacteriophage today (cp [8].), the Franco-Canadian Felix d'Herelle, in 1917, forwarded the most conclusive description of this multiplying agent. From the beginning, he forced the use of phage for therapeutic measures to kill pathogenic bacteria. In the twenties and thirties of the twentieth century, when he helped to establish the bacteriophage institute in Tbilisi, Georgia, he even wrote a book "Bacteriophage and the phenomenon of recovery" in Russian language [9]—see Fig. 2. Since then, this institute is a leading institution in the production and use of therapeutic phage. However, it has been argued that only few systematic studies were performed in Tbilisi and the clinical trials did not comply with internationally approved standards. This appraisal might have not considered those facts as military secrecy in Soviet Union, loss of documentation, and language barriers. Therefore, the Tbilisi colleagues published conclusive overviews demonstrating the methods and results of their studies $[8,10,11]$.

Until World War II, phage preparations were produced and used in Europe, Asia, and America [12]. One has to envision that, at this time, nobody had beheld these virus particles. By use of the newly developed electron microscope, Helmut Ruska, a medical doctor at the Charité Medical School in Berlin, visualized phage and phage-induced lysis of bacteria for the first time (cp. [13]).

Production of phage preparations for therapeutic use continued also after World War II but ceased during the next decennia because of the "triumphal procession" of antibiotics. Instead, phage became momentous experimental models contributing to the rapid development of molecular biology [14]. Scientific milestones such as the heredity role of DNA, the uncovering of the genetic code, the discovery of restriction-modification systems, and CRISPRCas in bacteria or the capability of viruses to integrate into the host genome are due to basic research on phage.

Phage preparation in France stopped as late as in the 1990s. This decision appears something paradoxically since this was the time of the beginning "antibiotics crisis". However, French pharmaceutical legislation responding to the AIDS crisis forbade any quantities of 'viruses' in medicinal products [11]. From the discovery of bacteriophage at the beginning of the twentieth century till nowadays, they were applied to cure bacterial infections in the former Soviet Union and in Poland, but were more or less ignored in Western medicine [15].

Numerous excellent overviews have been published on the history and clinical use of phage therapy [2, 15-25]. Until today, the number of controlled clinical studies to 

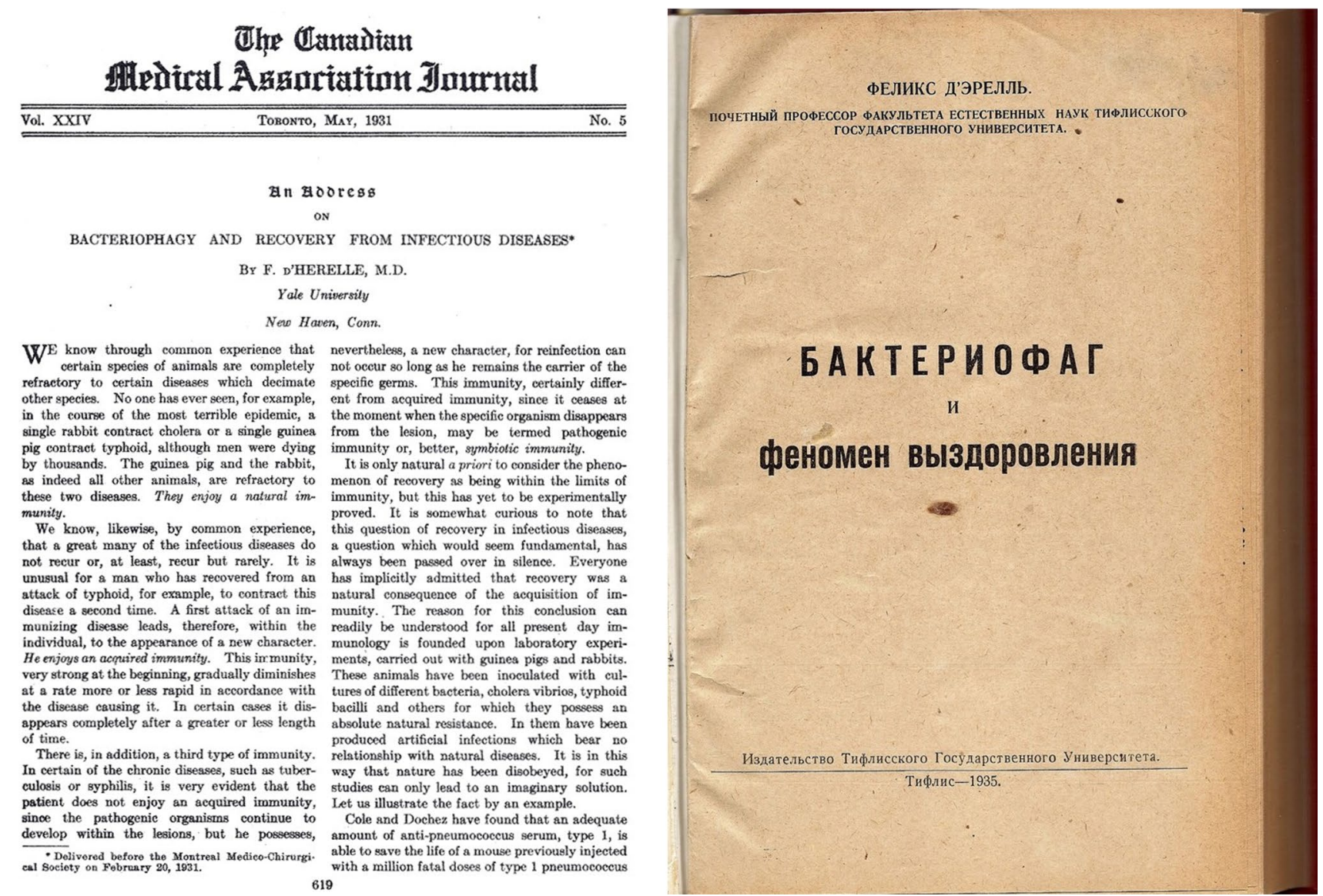

Fig. 2 Homage to Felix d'Herelle: Contribution to the Canadian Medical Association Journal in 1931 (left) and title page of a book published in Tbilisi, Georgia, former Soviet Union, in 1935 (right) (from the archive of the authors)

demonstrate the efficiency of therapy is limited and studies did not demonstrate credible efficacy in all cases. For major controlled studies, see references [26-30]. Older studies have been summarized by Abedon et al. [11].

\section{Use of phage in military medicine}

Even the discovery of bacteriophage by Felix d'Herelle had a military origin. 1915, during World War I, a group of soldiers in the outskirts of Paris suffered from a severe dysentery outbreak. Working with their fecal samples, d'Herelle observed an activity lysing bacteria, which could not be retained by bacterial filters [31].

During World War II, phages were used for the treatment of mainly intestinal and wound infections, which frequently occurred in the field, e.g., dysentery, gangrene, cholera, and infections by staphylococci. In the Soviet Union, the army was provided with huge amounts of phage in the form of vials and pills. Not only the institute in Tbilisi but also some other places in the Soviet Union were included in this mass production of phage, which were used for therapeutic and prophylactic purposes as well $[12,15,32]$. First use of phage in this war happened in November 1939 when Soviet troops started a campaign against Finland and undertook phage treatment of anaerobic wound infections leading to gangrene [31]. It has been reported that during the great battle of Stalingrad in 1942, when cholera outbreaks affected German and Soviet troops, phage was manufactured in a local Russian underground laboratory and has rescued the life of many soviet soldiers [33].

The German army used "Polyfagin," produced by the "Behringwerke Leverkusen," with the purpose to treat or prevent dysentery in soldiers. Polyfagin was a suspension containing phage specific for different Shigella strains. The fluid was given per os; to avoid phage inactivation during passage through the stomach, previous administration of a buffer substance (sodium bicarbonate) was recommended. The German army doctors observed some prophylactic and curative effect by Polyfagin. After their victory in Africa, the Allied troops confiscated some amount of Polyfagin from the Germans and used it-with limited success-to treat dysentery in a prisoner camp. Later one was found in the laboratory that the antibacterial activity of phage preparations was only low [12]. The US Army was also engaged in 
the development of phage therapeutics but it seems that the general opinion was rather skeptic [12]. Prophylactic and therapeutic uses of phage by military forces continue till today as reported from Georgian army during the 1991 and 1992 battles in Abkhazia and in the conflict with Russia in 2008 [34].

Today, in consideration of lethal infections by so-called ESKAPE pathogens (antibiotic-resistant Enterococcus faecium, Staphylococcus aureus, Klebsiella pneumoniae, Acinetobacter baumannii, Pseudomonas aeruginosa, Enterobacter species), which are of particular concern to injured soldiers, phage therapy is being re-evaluated also in military medicine and, moreover, even the generalized (intravenous) application of phage is accepted as treatment option. Recently, the US Navy was engaged in the successful treatment of a severely ill patient who consequently survived a highly critical Acinetobacter baumannii infection; the phage cocktail was given intravenously and percutaneously [35, 36].

In Europe, a multicenter study, "PhagoBurn", has been performed to evaluate phage therapy for the treatment of burn wounds infected with Escherichia coli and Pseudomonas aeruginosa; the French Ministry of Defense (through its Military Health Service and Percy Military Hospital) acted as Project Coordinator (https://www.phago burn.eu/). Unfortunately, the trial had to be stopped because of insufficient efficacy of the treatment. Some reasons for this failure have been discussed [26, 27]. Nevertheless, the Queen Astrid Military Hospital in Belgium-also involved in the PhagoBurn study - plays an important role in the first routine treatments with phage in the West since the 1980s under the Magistral Framework [37].

\section{Approaches for detection and treatment of "Category A priority pathogens"}

The US National Institute of Allergy and Infectious Diseases (NIAID), together with the Centers for Disease Control and Prevention (CDC), has categorized dangerous pathogens. According to their definition, category A pathogens are those organisms/biological agents that pose the highest risk to national security and public health because they (i) can be easily disseminated or transmitted from person to person, (ii) result in high mortality rates and have the potential for major public health impact, (iii) might cause public panic and social disruption, and (iv) require special action for public health preparedness. The list of Category A pathogens includes some viruses (smallpox and other related pox viruses, hemorrhagic fever viruses as members of arena-, bunya-, hanta-, flavi-, and filoviruses) and the following bacteria: Bacillus anthracis (anthrax), Clostridium botulinum toxin (botulism), Yersinia pestis (plague), and
Francisella tularensis (tularemia) (https://www.niaid.nih. gov/research/emerging-infectious-diseases-pathogens).

Most progress was made with Bacillus anthracis phage, which are able to interact with encapsidated, non-encapsidated, and spore forms of this pathogen [38]. Members of this phage group can be used for pathogen detection, spore decontamination, foodborne pathogen disinfection, and anthrax treatment [39]. Engineered B. anthracis reporter phages, which transduce bioluminescence markers to anthrax bacteria and their spores, were developed for pathogen detection [40]. Bacillus phage lysin was shown to act against vegetative cells and germinating spores of Bacillus anthracis and can be used as tools for treatment and detection of $B$. anthracis [41, 42]. Moreover, it was shown that a capsular depolymerase encoded by a $B$. subtilis phage improved phagocytic killing of encapsulated Bacillus anthracis both in vitro and in vivo [43, 44].

Very recently, a vaccine simultaneously protecting against infections by two category A pathogens, Bacillus anthracis and Yersinia pestis, was developed on the basis of a phage T4 platform. The bacterial antigens were fused with a small outer capsid protein of T4. In animal models, the vaccine provided protection against inhalational anthrax and/or pneumonic plague [45].

Yersinia pestis phages were used in first treatment experiments of plague. However, open questions remain, e.g., the susceptibility of bacteria intracellularly located in macrophages, the danger of endotoxic shock, and the introduction of an animal model better suited than mice [46]. Bioluminescent Yersinia pestis reporter phage can be used for rapid detection (and simultaneous antibiotic susceptibility analysis) of plague bacteria [40, 47].

The list of Category A pathogens-associated bacteriophage is mainly limited to $B$. anthracis and $Y$. pestis phage [48]. Progress in the practical use of Clostridium botulinum phage seems to be rather limited because cell killing of this endotoxin-containing bacterium can be dangerous for the organism [12]. For some forms of the disease, uptake of the botulinum toxin instead of bacterial infection is sufficient and, moreover, some toxins are encoded by prophage in the bacterium [49]. Even less is known about phage of Francisella tularensis and their practical use [50]; https://pcwww .liv.ac.uk/ hallison/EMBOVoM2016/data/abstracts/abstr act_213.html).

\section{Scientific challenges to select the "ideal" phage}

In this chapter, we will try to define criteria for the selection of therapeutic phage. Since a complete genomic characterization of phage will be a necessary precondition for their approval in a regulatory framework $[51,52]$, we will also 
discuss the use of genomic data for a putative prediction of relevant phenotypic properties of phage.

\section{Temperate vs. virulent character of phage}

It is generally accepted that phage for therapeutic use should be strictly virulent (lytic) without ability to lysogenize the target cell. In other words, all temperate phages have to be excluded from the collection of potential therapeutics. The lifestyle of a phage — virulent or temperate — can be analyzed by microbiological techniques [53].

Based on genome sequencing, the findings of repressor motifs putatively speak for a temperate phage. Detection of integrase or transposase motifs or genomic attachment (att) sites should also be important for the classification of a phage as being obligatory temperate. However, it is known that certain temperate phages do not need to integrate their genome into the cell chromosome, but are maintained in an episomal state. There are also attempts to distinguish virulent vs. temperate phage by in silico analyses of phage genome compositions including relative abundances of di-, tri-, and tetranucleotides from entire phage genomes [54, 55].

\section{Presence of virulence, toxin, or resistance genes}

Phage genomes should be screened to avoid the presence of these potentially dangerous genetic determinants. However, in rare cases, genomes of virulent phage contain essential genes, which seem to be homologs of pathogenicity-associated bacterial genes. Still, it has been argued that they might be considered as therapeutic phage [56].

\section{Transduction ability}

Therapeutic phage should not have the ability to transduce bacterial genes, which could include virulence, toxin, and antibiotics resistance genes. Therefore, potential therapeutic phage should be investigated for their general ability to perform transduction. Bothering genes being transduced could be originate from bacteria in the organism of the patient or from cells used for phage production in the laboratory. Therefore, bacterial strains for phage production should undergo control to show the absence of those genes. However, especially for some target bacteria, it may not be possible to find production strains that are both functional and plausibly clean $[52,57]$.

In generalized transduction any fragment of the bacterial genome can be packaged into phage capsid and transferred to another bacterial cell. This process can occur with members of both virulent and temperate phage. The ability of generalized transduction appears to depend on the genome packaging mechanism of phage. Phage with packaging initiation from non- or low-specific DNA sequences are considered to accept also foreign genetic material during maturation. However, some phages, as classical T3 and T7 [58], require specific sequences in their genomes to initiate DNA packaging; therefore, they should be unable to attach and insert foreign genetic material. Moreover, phages that degrade the DNA of the infected cell and use it as building blocks for their own genomes should be considered as non-transducers [53]. Generalized transducing phages can be predicted by microbiological techniques (testing the ability to transfer easily selectable markers between bacterial strains) or by PCR-based techniques (testing the presence of bacterial DNA in purified phage particles). In addition to the use of sequencing and bioinformatic prediction programs, one can remember classical phage techniques to assess the transduction ability of a phage [53].

In specialized transduction, induction of a prophage can lead to additional packaging of neighboring bacterial genes into the phage particles. Therefore, specialized transduction can be only performed by temperate phage, which, however, should be excluded from therapeutic use. To predict the ability of a phage for special transduction, one can also search for motifs of integrase-encoding genes or attachment (att) regions.

\section{Narrow vs. broad host range, monospecific phage vs. phage cocktails}

Regarding the host range of bacteriophage, one has to find a compromise between very near and very broad. A host range focused on a particular pathogenic bacterial strain has the disadvantage that even other (pathogenic) strains of the same species might be not affected. On the other side, phage with a broad host range could also kill beneficial bacteria, which are part of the normal microbiome in the organism. Probably optimal are phages, which affect all members of a bacterial species but are without cross-activity against other species [53, 59].

To execute a "personalized medicine" one could define the pathogenic strains in an individual and chose specific phage for their treatment. The personalized medicine model involves the creation of a large bank of phage manufactured in advance as "Active Pharmaceutical Ingredients" (APIs), the members of this bank are then tested for activity against a patient's clinical isolate using some form of companion diagnostic device, and active phages are then formulated into a medicinal product that is unique to the patient. This model being worked on in both the US and Europe is in opposition to a fixed drug model.

In the "fixed drug model," use of phage cocktails encompassing phage of different specificity allows the treatment of mixed infections. This could be advantageous for clinical purposes [60]. The broader the host range of the phage 
involved, the more economically advantageous the therapy will be. However, the development of phage resistance in each specific phage-pathogen dyad should not be reduced by the presence of other phage in a cocktail.

\section{Emergence of phage-resistant bacteria}

Under the selective pressure of phage therapy, phage-resistant bacteria can emerge. While certain bacterial strains may remain susceptible to a given phage for tens of generations, cells resistant to the same phage may appear in populations of other strains of the same species after a few generations [53]. To reduce this risk, the use of multispecific phage cocktails is recommended since the times of Felix d'Herelle; however, this principle might have some weakness (see previous chapter).

It has been argued that antibiotic-resistant bacteria, when becoming also phage-resistant, could regain their antibiotic sensitivity. However, the markers of antibiotic and phage sensitivities usually are not coupled-this is the basis of the phage therapy concept. Rather exceptionally, a Pseudomonas phage was described, which uses an outer membrane protein of a multidrug efflux system as receptor-binding site; development of phage resistance inhibited the drug efflux and increased the antibiotic sensitivity of the cells [61]. Likewise, phages that bind structural virulence factors such as capsular antigen can select phage-resistant bacterial mutants that lack the capsule and are less virulent because they can be more easily recognized by phagocytes [62].

\section{Ability to overcome defense systems of the bacterial cell}

After invasion of the bacterial cell, the phages have to overcome various defense systems of the cell; these countermeasures can work on the levels of the individual cell or the bacterial population [63]. Phage genomes can be attacked by systems as the classical DNA restriction/modification or CRISPR-Cas; however, in their evolution, the phages have developed multiple mechanisms to overcome these defense systems [64-66]. Whereas "defense islands" in the prokaryotic genomes can be characterized [67], it is too early to predict the existence of general anti-restriction properties from the nucleotide sequence of the phage.

\section{Lysis or lysis-free killing of bacteria}

Simultaneous killing of endotoxin-producing cells was traditionally assumed to result in an endotoxic shock in the affected individual. The construction of non-replicative and/or lysis-deficient phage may circumvent this problem [68-71]. However, those phage would be unable to replicate in the cell; this fact contradicts a crucial advantage of phage therapy-the phage enrichment at the site of bacterial infection in the organism. Moreover, at least to our knowledge, cases of the postulated endotoxic shock have not been reported. One could speculate that phages lyse bacteria in a more "gentle "way than bacteriolytic antibiotics known to induce endotoxic shock.

\section{Use of viable phage vs. phage-derived enzymes}

Figure 3 compares some important characteristics of viable phage vs. purified phage enzymes as antimicrobials. The pros and cons seem to be rather uniformly distributed. Unwanted risks of phage use concern rapid resistance development in the bacteria and genetic instability of phage as replicating pathogens. In contrast, purified phage enzymes as stable proteins could have better chances to get approval by official authorities. However, antimicrobial activity of endolysins in vitro was reported to be dependent on multiple parameters such as $\mathrm{pH}$ range, buffer conditions, temperature, and ionic strength nicely reviewed by Oliveira et al. [72]. The authors emphasize that virion-associated lysins (VALs, see below) may have even greater therapeutic potential than endolysins because, as component on the surface of the virion, they have to maintain activity in different environmental conditions. Altogether, comparisons between phage and phage-derived enzymes should attract more attention. Probably, only the combination of different antimicrobial

\begin{tabular}{|l|l|l|}
\hline Feature & Viable phage \\
\hline Host specificity & $\begin{array}{l}\text { Purified phage } \\
\text { enzymes }\end{array}$ \\
\hline $\begin{array}{l}\text { Self-enrichment at the site } \\
\text { of treatment }\end{array}$ & \\
\hline $\begin{array}{l}\text { Clearance by RES* in the } \\
\text { macroorganism }\end{array}$ & \\
\hline $\begin{array}{l}\text { Stable/active under } \\
\text { numerous environmental } \\
\text { conditions }\end{array}$ & \\
\hline $\begin{array}{l}\text { Resistance development of } \\
\text { bacteria }\end{array}$ & \\
\hline Genetic stability & \\
\hline Possibility for engineering & \\
\hline
\end{tabular}

*RES: reticuloendothelial system

Fig. 3 Pros and cons in the use of viable phage vs. phage enzymes for therapeutic approaches. (-) represents a beneficial, (2) a harmful characteristic of phage and phage-derived enzymes, respectively, with regard to antimicrobial therapy 
treatment options (including antibiotics) will increase the repertoire to combat multiresistant bacterial pathogens. For further details, see chapter 8 of this review.

\section{Ability to treat bacteria in biofilms}

A particular challenge is the treatment of pathogenic, antibiotic-resistant bacteria, which are parts of biofilms in the organism. Biofilms are complex bacterial communities kept together by an extracellular polymer matrix of exopolysaccharides, proteins, nucleic acids, and lipids. Biofilms represent an effective bacterial survival strategy because bacteria therein reach highly increased protection against antimicrobial agents compared to their planktonic counterparts [73-76].

Phage can be used to reduce biofilms on medical devices in the organism, as maintenance catheters or implants [77]. Some review papers have addressed the possible susceptibility of biofilm to phage and phage-derived enzymes, e.g., $[74,78-81]$. For these studies, a critical point is the quality of the in vitro models used and how realistically they are able to simulate the complex in vivo conditions [74, 78-81]. Especially, phage-coded depolymerases that disassemble superficial polysaccharides on bacteria into smaller units are advantageous as they can weaken biofilms and make them vulnerable for an antibiotic treatment.

\section{Phage engineering for pathogen treatment}

Phage engineering is an area of research that is attracting intense interest and has great potential to enhance phage' antimicrobial activity for pathogen treatment. Several original papers and reviews present techniques successfully applied to engineer phage [82-94]. Companies in several countries already take advantage of the methods described in the following chapter. Sophisticated molecular biological techniques, developments in synthetic biology, and fast and low-cost DNA sequencing methods provide technical preconditions to optimize phage for their increased antimicrobial effectiveness and efficiency [95].

Very recently, the first use of engineered phage to treat a severe disseminated Mycobacterium abcessus infection in a 15 -year-old cystic fibrosis patient was reported. Lytic phage derivatives, which effectively killed the pathogen, were developed by Bacteriophage Recombineering of Electroporated DNA (BRED) to eliminate a phage repressor gene and by genetic selection of host range mutants. Intravenous therapy using a three-phage cocktail, conducted for 32 weeks, was well tolerated and was associated with significant clinical improvement [96].

\section{Enhanced antimicrobial activity}

To enhance the bactericidal effect, phage can be altered either to enter the target cell or to damage the cell after entry more efficiently. To the first aim, Scholl et al. designed a T7 construct with the K1-5 endosialidase gene cloned downstream of the major capsid gene of $\mathrm{T} 7$ ( $\left.\mathrm{T} 7_{\text {endo }}\right)$. The endosialidase was produced and released into the lysate after $\mathrm{T} 77_{\text {endo }}$ infection and lysis of the host cells. $\mathrm{T} 7_{\text {endo }}$, in contrast to wild-type T7, allowed the phage to infect also capsuleproducing E. coli cells [97]. Lu and Collins equipped phage T7 with gene dspB from Actinobacillus actinomycetemcomitans that confers biofilm-degrading activity to $\mathrm{T} 7$ by Dispersin B [98]. The engineered T7 phage reduced bacterial biofilm cell counts by two orders of magnitude when compared with wild-type T7.

An alternative approach is to introduce genes into the phage genome, the products of which severely interfere with functional cellular networks. The same authors engineered the non-lytic filamentous phage M13mp18 to produce the Lex3 repressor of the SOS response [99]. Antibiotic treatment induces hydroxyl radical formation that leads to DNA, protein, and lipid damage and eventually to cell death. DNA damage in turn induces the SOS response resulting in DNA repair. By preventing the repair process, the engineered M13mp18 enhanced antibiotic-induced killing of Escherichia coli in vivo and in vitro.

In another study, phage T7 was engineered to express a lactonase enzyme with broad-range activity to disturb quorum-sensing [100]. Most bacteria use this biochemical communication process to coordinate the behavior of individual bacterial cells in a group by small molecules (acyl homoserine lactones, AHL). Quorum sensing is a pre-requisite for biofilm formation that displays an important pathogenicity marker. T7 lactonase produced by a recombinant $\mathrm{T} 7$ variant degrades essential small AHL autoinducer molecules and inhibited biofilm formation by a mixture of Escherichia coli and Pseudomonas aeruginosa [100]. A further route is to introduce "lethal genes" into bacteria that (i) restore bacterial susceptibility to antibiotics [101], (ii) reduce the bacterial population $[68,69,102]$, or (iii) achieve endocytosis of engineered phage into eukaryotic cells to combat intracellularly replicating pathogens [103]. Other studies showed how phage therapy becomes more effective by encapsulating phage in liposomes delivered to treat intracellular bacteria [104].

\section{Altered host range}

Currently, the most common approach to achieve a wider bacterial spectrum is the combination of phage with different host range. An alternative to use such cocktails may be to change and/or expand the host range of a phage by 
genetic engineering. There are several examples in the literature where the host range of phage was altered by adding or swapping of receptor-binding domains [105-110]. Improved technologies for phage engineering, DNA synthesis, and DNA sequencing might allow the construction of defined phage cocktails with variable host ranges.

\section{Development of DNA sequence-specific targeting antimicrobials}

One critical issue with antibiotics is their lack of specificity, which leads to the killing not only of targeted pathogens, but also of non-targeted commensal bacteria. This effect can alter the composition and the balance of a microbiome and result in antibiotic-associated severe infections. To avoid negative side effects, the development of sequence-specific antimicrobials based on controllable CRISPR-Cas nucleases seems a valuable option. Bikard et al. selectively attacked virulence genes of Staphylococcus aureus by RNA-guided Cas9 nuclease and thereby killed the virulent, but not avirulent bacteria [87]. The efficiency of this method was confirmed in vivo in a mouse model. Citorek et al. used the same tool to induce cell death or plasmid loss upon detection of genetic signatures derived from virulence or antibiotic resistance genes in carbapenem-resistant Enterbacteriaceae and enterohemorrhagic Escherichia coli [86]. Yosef et al. used an engineered temperate phage delivering the CRISPR-Cas system together with an engineered lytic phage to re-sensitize bacteria to antibiotics and selectively kill antibioticresistant bacterial cells [89].

\section{Prolonged circulation time in the macroorganism}

Another concern is that the human immune system neutralizes the therapeutic phage, particularly if administered systemically. In a murine model of systemic inflammatory response, the count of viable phage decreased in circulation and in numerous tissues due to the action of phagocytes, antibodies, and serum complement [111]. There are two ways to counteract this problem: (i) the selection of longcirculating phage and (ii) the use of growth- and/or lysisdeficient phage. To avoid the problem of phage elimination by the reticuloendothelial system (RES) of the host, Merril et al. [112] serially injected phage (E. coli phage Lambda and $S$. typhimurium phage P22, resp.) into mice to search for phage mutants capable of remaining in the circulatory system for longer times. The isolated long-circulating phage mutants after ten selection cycles had approximately five orders of magnitude higher capacity to evade RES clearance than the wild-type phage tested $24 \mathrm{~h}$ after intraperitoneal administration. Lambda phage mutant obtained after selection had a relevant mutation in the major capsid protein E [112]. By using genetic engineering, Vitiello et al. introduced just this single mutation in the major capsid gene and obtained a similar longer circulating phage mutant [113]. Very recently, Nan et al. demonstrated that lytic phage T7, mutated by the expression of CD47-derived peptides, showed prolonged blood circulation and thereby dramatically increased antibacterial activity in mice in vivo [114].

Another idea to aid therapeutic phage to longer circulate in the organism is the use of phage which express orphan DNA methyltransferases (MTases) [115]. These DNA MTases exist solely, without a corresponding restriction endonuclease. Phage genomes with mono- or multispecific orphan DNA MTases confer protection against different restriction endonucleases of their host cell and thereby may prolong the effectiveness of phage therapy [115].

\section{Phage engineering for pathogen detection}

Phage engineering is also a versatile means for rapid detection and diagnostics of bacterial pathogens. Phages were altered genetically to express transgenes that after replication in the respective host produce luminescence $[116,117]$ or fluorescence signal [82, 118-121] that easily and quickly can be detected. If the pathogen searched for is absent, no signal appears. Especially important are these manipulated phage if they can detect Category A bacterial pathogens [39, 47, 122-124].

\section{Phage in selective drug delivery and vaccine development}

Filamentous phages were adapted for selective drug delivery to both prokaryotic and eukaryotic cells. Goals were (i) to amplify the potential of low-efficient drugs by creating a high concentration around the targeted bacterial cell (releasing the drug and tethering the phage), (ii) reduction of general toxicity because the drug is inactive as long as it is linked to the phage, and (iii) re-introduction of non-selective toxic substances as drug candidates against drug-resistant bacteria [125-128]. Very recently, engineered phage T4 was successfully used as vaccine against Category A pathogens. The authors consider phage $\mathrm{T} 4$ as a suitable nanoparticle platform to produce multivalent vaccines against high-risk pathogens [45].

\section{Phage in food and surface decontamination}

Numerous studies focused on the importance of applying phage for food and surface decontamination. Several phagebased products have received regulatory approval for treating food products. ListShield, EcoShield, and SalmoFresh 
from Intralytix control the respective foodborne bacterial pathogens such as Listeria monocytogenes, Escherichia coli O157:H7, and Salmonella enterica in foods or foodprocessing environments. Salmonelex and Listex P100 from Micreos reduce contamination with Salmonella and L. monocytogenes, resp., during food processing. Agriphage from OmniLytics controls Xanthomonas campestris and Pseudomonas syringae on tomato and pepper plants [129]. Several attempts were described applying phage in food-producing animals to reduce colonization of the animals with bacterial pathogens, e.g., E. coli, Salmonella spp.Campylobacterspp., Listeria and Serratia spp.[22, 129, 130].

\section{Engineering of phage enzymes}

Besides complete phage used as direct antimicrobials, also phage-derived enzymes as polysaccharide depolymerases and peptidoglycan-degrading enzymes are promising therapeutic candidates [131-140]. Many bacteria produce highmolecular weight polysaccharides present on the surface of the cell. These polysaccharides contribute to pathogenicity, protect bacteria from phagocytosis, can increase biofilm production, and are physical barriers to phage preventing access to their receptors. Phage have evolved to use polysaccharide structures as their primary receptors by having depolymerization activities in their neck, base plate, and/or tail fibers that degrade polymers to smaller subunits [133]. Phages with this property produce haloed plaques due to the production of free depolymerase enzymes that remove polysaccharides of the neighboring cells thereby conferring a great advantage in biofilm prevention or removal. Depolymerases do not lyse bacteria but sensitize them against antibiotics or other antimicrobials [141-143]. Pires et al. [133] have collected information about all depolymerases encoded by fully sequenced phage. They found 160 putative depolymerases in 143 double-stranded DNA phage infecting 24 genera of bacteria.

Peptidoglycan-degrading enzymes are phage-encoded enzymes that hydrolyze peptidoglycan layers in the bacterial cell wall, one to three layers in gram-negative and up to 40 layers in gram-positive bacteria [72, 144]. These enzymes can be located in the virion, often referred to as virion-associated lysins (VALs), and act during viral DNA entry. These enzymes attack the cell wall from outside and promote the injection of phage DNA. In contrast, endolysins normally accumulate in the cytoplasm and, via pores formed by phage-encoded holins, they reach the peptidoglycans and disrupt them $[72,145]$. Endolysins and holins are required for the programmed host cell lysis during progeny phage release in the end of a productive phage replication. Purified lysins also can lyse bacterial cultures in vitro. VALs and endolysins are categorized according to the peptidoglycan bond they cleave into different classes. The enzymatic diversity of these enzymes is remarkable [72].

To exploit endolysins as efficient antimicrobials against gram-negative pathogens with an impermeable outer membrane, they were combined with lipopolysaccharide-destabilizing peptides that render these "artilysins" able to pass the outer membrane [131, 146-148]. Artilysin ${ }^{\circledR}$ Art-175 is very effective also against highly resistant strains of Pseudomonas aeruginosa and Acinetobacter baumannii [149]. Generally, they are species-specific thereby allowing selective killing of a given pathogen saving accompanying microflora [138]. The effect of the degrading activity of endolysins can be demonstrated in seconds as osmotic lysis of the targeted cell [135]. For an improved antimicrobial activity, endolysins were also combined with holin [150] or depolymerase [151] against Staphylococcus aureus/S. suis and $S$. aureus biofilms, respectively. Moreover, the right combination of phage lytic proteins and antibiotics or bacteriocins significantly increased survival in animal experiments [134, 152-154]. Application of phage-derived enzymes in various model systems was excellently summarized recently [134, 135].

Modular organization of phage endolysins in distinct functional domains-catalytic and cell wall binding domain(s) connected by linker sequences-provides the proteins with two useful properties: a remarkable substrate specificity and it allows protein engineering in order to design new proteins with enhanced antimicrobial activities [133, 134, 138, 147-149, 155]. Design of new enzymes by deletion and shuffling of domains, synthesis of truncated proteins, and production of chimeric enzymes by combining domains from different lytic proteins ("chimeolysins") have shown good results with regard to the development of improved lytic proteins [134, 156, 157]. This includes not only the ability to change binding and catalytic specificity, but also protein solubility and thermostability [138]. Sobieraj et al. reported the fusion of a staphylococcal endolysin to an albumin-binding domain that increased the half-life of the proteins [158]. Wang et al. combined an endolysin from a Staphylococcus aureus phage with a cell-penetrating peptide that facilitates crossing of the eukaryotic membrane by the lytic protein and thereby can kill intracellular infections by S. aureus [157]. A first product containing an endolysin for use in humans is available on the market (Staphefekt, Gladskin brand). This product is recommended for the treatment of early stages of $S$. aureus-related skin infections [134]. Resistance acquisition to lysins has not been observed so far. This may be due to the fact that their targets in the peptidoglycan molecule are essential for bacterial viability and mutations would be to harmful to the bacteria $[134,159$, 160]. 
A great advantage of phage-derived enzymes over traditional antibiotics is their ability to lyse bacteria in biofilms even if they are non-replicative and are also active against persister cells (see above) [134]. Genetic screens [132, 161] or metagenomic sequences of uncultured viral populations and bacteriophage genomic libraries are sources to search for new active phage lytic enzymes [162].

\section{Outlook}

In the era of emerging antibiotic resistances, there is a high need to force developments in the therapeutic use of phage and phage-derived enzymes. More controlled clinical studies are necessary to evaluate the usefulness of this strategy and efforts are required to guarantee defined formula, titer, stability, and purity of phage preparations. On this basis, regulatory issues have to be solved - this might be easily manageable for defined standard preparations but requires also clues for "individualized" preparations using phage specifically selected to treat the diagnosed pathogens of a particular patient.

Acknowledgements The authors thank Deutsche Forschungsgemeinschaft for long-term support of their work on bacteriophage and bacterial restriction endonucleases. We are grateful to Bob Blasdel (Leuven) and Udo Bläsi (Vienna) for critical reading of the manuscript and helpful suggestions. Nevertheless, the authors are responsible for all putative weaknesses of the paper.

\section{Compliance with ethical standards}

Conflict of interest The authors declare that there is no conflict of interest.

Ethical approval This article does not contain any studies with human participants or animals performed by the authors.

\section{References}

1. Bassetti M, Poulakou G, Ruppe E, Bouza E, Van Hal SJ, Brink A (2017) Antimicrobial resistance in the next 30 years, humankind, bugs and drugs: a visionary approach. Intensive Care Med 43:1464-1475

2. Rios AC, Moutinho CG, Pinto FC, Del Fiol FS, Jozala A, Chaud MV, Vila MM, Teixeira JA, Balcao VM (2016) Alternatives to overcoming bacterial resistances: State-of-the-art. Microbiol Res 191:51-80

3. Williams JJ, Hergenrother PJ (2008) Exposing plasmids as the Achilles' heel of drug-resistant bacteria. Curr Opin Chem Biol 12:389-399

4. Liu J, Dehbi M, Moeck G, Arhin F, Bauda P, Bergeron D, Callejo M, Ferretti V, Ha N, Kwan T, McCarty J, Srikumar R, Williams D, Wu JJ, Gros P, Pelletier J, Dubow M (2004) Antimicrobial drug discovery through bacteriophage genomics. Nat Biotechnol 22:185-191
5. Holmes AH, Moore LS, Sundsfjord A, Steinbakk M, Regmi S, Karkey A, Guerin PJ, Piddock LJ (2016) Understanding the mechanisms and drivers of antimicrobial resistance. Lancet 387:176-187

6. Czaplewski L, Bax R, Clokie M, Dawson M, Fairhead H, Fischetti VA, Foster S, Gilmore BF, Hancock RE, Harper D, Henderson IR, Hilpert K, Jones BV, Kadioglu A, Knowles D, Olafsdottir S, Payne D, Projan S, Shaunak S, Silverman J, Thomas CM, Trust TJ, Warn P, Rex JH (2016) Alternatives to antibioticsa pipeline portfolio review. Lancet Infect Dis 16:239-251

7. Clokie MR, Millard AD, Letarov AV, Heaphy S (2011) Phages in nature. Bacteriophage 1:31-45

8. Chanishvili N (2016) Bacteriophages as therapeutic and prophylactic means: summary of the soviet and post soviet experiences. Curr Drug Deliv 13:309-323

9. D'Herelle F (1935) Bacteriophagy and recovery from infectious diseases. Tbilisi University Press, Tbilisi

10. Kutateladze M, Adamia R (2010) Bacteriophages as potential new therapeutics to replace or supplement antibiotics. Trends Biotechnol 28:591-595

11. Abedon ST, Kuhl SJ, Blasdel BG, Kutter EM (2011) Phage treatment of human infections. Bacteriophage 1:66-85

12. Häusler T (2003) Gesund durch Viren. Ein Ausweg aus der Antibiotika-Krise. Piper, München, Zürich

13. Kruger DH, Schneck P, Gelderblom HR (2000) Helmut Ruska and the visualisation of viruses. Lancet 355:1713-1717

14. Cairns J, Stent GS, Watson JG (1966) Phage and the origins of molecular biology. Cold Spring Harbor Laboratory, New York

15. Chanishvili N (2012) Phage therapy-history from Twort and d'Herelle through Soviet experience to current approaches. Adv Virus Res 83:3-40

16. Vandenheuvel D, Lavigne R, Brussow H (2015) Bacteriophage therapy: advances in formulation strategies and human clinical trials. Annu Rev Virol 2:599-618

17. Cisek AA, Dabrowska I, Gregorczyk KP, Wyzewski Z (2017) Phage therapy in bacterial infections treatment: one hundred years after the discovery of bacteriophages. Curr Microbiol 74:277-283

18. Rohde C, Wittmann J, Kutter E (2018) Bacteriophages: a therapy concept against multi-drug-resistant bacteria. Surg Infect 19:737-744

19. Kutter EM, Borysowski J, Miedzybrodski R, Gorski A, WeberDabrowska B, Kutateladze M, Alavidze Z, Goderdzishvili M, Adamia R (2014) Clinical phage therapy. In: Borysowski J (ed) Phage therapy: current research and applications. Caister Academic Press, Norfolk, pp 257-288

20. Kutter E, De VD, Gvasalia G, Alavidze Z, Gogokhia L, Kuhl S, Abedon ST (2010) Phage therapy in clinical practice: treatment of human infections. Curr Pharm Biotechnol 11:69-86

21. Abedon ST (2017) Bacteriophage clinical use as antibacterial "drugs": utility and precedent. Microbiol Spectrum 5:BAD-0003-2016

22. Abedon ST, Garcia P, Mullany P, Aminov R (2017) Editorial: phage therapy: past, present and future. Front Microbiol 8:981

23. Abedon ST, Thomas-Abedon C, Thomas A, Mazure H (2011) Bacteriophage prehistory: is or is not Hankin, 1896, a phage reference? Bacteriophage 1:174-178

24. Wittebole X, De RS, Opal SM (2014) A historical overview of bacteriophage therapy as an alternative to antibiotics for the treatment of bacterial pathogens. Virulence 5:226-235

25. Kortright KE, Chan BK, Koff JL, Turner PE (2019) Phage therapy: a renewed approach to combat antibiotic-resistant bacteria. Cell Host Microbe 25:219-232

26. Jault P, Leclerc T, Jennes S, Pirnay JP, Que YA, Resch G, Rousseau AF, Ravat F, Carsin H, Le FR, Schaal JV, Soler C, Fevre C, Arnaud I, Bretaudeau L, Gabard J (2019) Efficacy and tolerability 
of a cocktail of bacteriophages to treat burn wounds infected by Pseudomonas aeruginosa (PhagoBurn): a randomised, controlled, double-blind phase 1/2 trial. Lancet Infect Dis 19:35-45

27. Sarker SA, Sultana S, Reuteler G, Moine D, Descombes P, Charton F, Bourdin G, McCallin S, Ngom-Bru C, Neville T, Akter M (2016) Oral phage therapy of acute bacterial diarrhea with two coliphage preparations: a randomized trial in children from Bangladesh. EBioMedicine 4:124-137

28. Ujmajuridze A, Chanishvili N, Goderdzishvili M, Leitner L, Mehnert U, Chkhotua A, Kessler TM, Sybesma W (2018) Adapted bacteriophages for treating urinary tract infections. Front Microbiol 9:1832

29. Febvre HP, Rao S, Gindin M, Goodwin NDM, Finer E, Vivanco JS, Lu S, Manter DK, Wallace TC, Weir TL (2019) PHAGE study: effects of supplemental bacteriophage intake on inflammation and gut microbiota in healthy adults. Nutrients 11:666

30. Wright A, Hawkins CH, Anggard EE, Harper DR (2009) A controlled clinical trial of a therapeutic bacteriophage preparation in chronic otitis due to antibiotic-resistant Pseudomonas aeruginosa; a preliminary report of efficacy. Clin Otolaryngol 34:349-357

31. Myelnikov D (2018) An alternative cure: the adoption and survival of bacteriophage therapy in the USSR, 1922-1955. J Hist Med Allied Sci 73:385-411

32. Gelman D, Eisenkraft A, Chanishvili N, Nachman D, Coppenhagem GS, Hazan R (2018) The history and promising future of phage therapy in the military service. J Trauma Acute Care Surg 85:S18-S26

33. Dabizheva AN, Voroshilova NN, Prisada TV, Efimova MG (2017) Phages attack. A history of bacteriophage production and therapeutic use in Russia. Sci First Hand (Novosibirsk) 46:1

34. Jones EH (2019) Neat science in a messy world: the global impact of human behaviour and phage therapy, past and present. Phage Ther Appl Res 1:10-16

35. Schooley RT, Biswas B, Gill JJ, Hernandez-Morales A, Lancaster J, Lessor L, Barr JJ, Reed SL, Rohwer F, Benler S, Segall AM, Taplitz R, Smith DM, Kerr K, Kumaraswamy M, Nizet V, Lin L, McCauley MD, Strathdee SA, Benson CA, Pope RK, Leroux BM, Picel AC, Mateczun AJ, Cilwa KE, Regeimbal JM, Estrella LA, Wolfe DM, Henry MS, Quinones J, Salka S, Bishop-Lilly KA, Young R, Hamilton T (2017) Development and use of personalized bacteriophage-based therapeutic cocktails to treat a patient with a disseminated resistant Acinetobacter baumannii infection. Antimicrob Agents Chemother 61:e00954-17

36. Bootman E (2018) First phage therapy center in the U.S. signals growing acceptance. https://www.statnews.com/2018/06/21/ phage-therapy-viruses-carl-merril-navy.

37. Pirnay JP, Verbeken G, Ceyssens PJ, Huys I, De VD, Ameloot C, Fauconnier A (2018) The magistral phage. Viruses 10:64

38. Gillis A, Mahillon J (2014) Phages preying on Bacillus anthracis, Bacillus cereus, and Bacillus thuringiensis: past, present and future. Viruses 6:2623-2672

39. Jonczyk-Matysiak E, Klak M, Weber-Dabrowska B, Borysowski J, Gorski A (2014) Possible use of bacteriophages active against Bacillus anthracis and other B. cereus group members in the face of a bioterrorism threat. Biomed Res Int. https://doi. org/10.1155/2014/735413

40. Sharp NJ, Molineux IJ, Page MA, Schofield DA (2016) Rapid Detection of Viable Bacillus anthracis Spores in Environmental Samples by Using Engineered Reporter Phages. Appl Environ Microbiol 82:2380-2387

41. Schuch R, Nelson D, Fischetti VA (2002) A bacteriolytic agent that detects and kills Bacillus anthracis. Nature 418:884-889

42. Schuch R, Pelzek AJ, Raz A, Euler CW, Ryan PA, Winer BY, Farnsworth A, Bhaskaran SS, Stebbins CE, Xu Y, Clifford A, Bearss DJ, Vankayalapati H, Goldberg AR, Fischetti VA (2013)
Use of a bacteriophage lysin to identify a novel target for antimicrobial development. PLoS ONE 8:e60754

43. Scorpio A, Chabot DJ, Day WA (2007) O'brien DK, Vietri NJ, Itoh Y, Mohamadzadeh M, Friedlander AM: Poly-gamma-glutamate capsule-degrading enzyme treatment enhances phagocytosis and killing of encapsulated Bacillus anthracis. Antimicrob Agents Chemother 51:215-222

44. Scorpio A, Tobery SA, Ribot WJ, Friedlander AM (2008) Treatment of experimental anthrax with recombinant capsule depolymerase. Antimicrob Agents Chemother 52:1014-1020

45. Tao P, Mahalingam M, Zhu J, Moayeri M, Sha J, Lawrence WS, Leppla SH, Chopra AK, Rao VB (2018) A bacteriophage T4 nanoparticle-based dual vaccine against anthrax and plague. MBio 9:e01926-18

46. Filippov AA, Sergueev KV, Nikolich MP (2012) Can phage effectively treat multidrug-resistant plague? Bacteriophage 2:186-189

47. Vandamm JP, Rajanna C, Sharp NJ, Molineux IJ, Schofield DA (2014) Rapid detection and simultaneous antibiotic susceptibility analysis of Yersinia pestis directly from clinical specimens by use of reporter phage. J Clin Microbiol 52:2998-3003

48. Filippov AA, Sergueev KV, Nikolich MP (2013) Bacteriophages against biothreat bacteria: diagnostic, environmental and therapeutic applications. J Bioterr Biodef S3:010

49. Brussow H, Canchaya C, Hardt WD (2004) Phages and the evolution of bacterial pathogens: from genomic rearrangements to lysogenic conversion. Microbiol Mol Biol Rev 68:560-602

50. Boisset S, Caspar Y, Sutera V, Maurin M (2014) New therapeutic approaches for treatment of tularaemia: a review. Front Cell Infect Microbiol 4:40

51. Philipson CW, Voegtly LJ, Lueder MR, Long KA, Rice GK, Frey KG, Biswas B, Cer RZ, Hamilton T, Bishop-Lilly KA (2018) Characterizing phage genomes for therapeutic applications. Viruses 10:188

52. Pirnay JP, Blasdel BG, Bretaudeau L, Buckling A, Chanishvili N, Clark JR, Corte-Real S, Debarbieux L, Dublanchet A, De VD, Gabard J, Garcia M, Goderdzishvili M, Gorski A, Hardcastle J, Huys I, Kutter E, Lavigne R, Merabishvili M, Olchawa E, Parikka KJ, Patey O, Pouilot F, Resch G, Rohde C, Scheres J, Skurnik M, Vaneechoutte M, Van PL, Verbeken G, Zizi M, Van den Eede G (2015) Quality and safety requirements for sustainable phage therapy products. Pharm Res 32:2173-2179

53. Lobocka M, Hejnowicz MS, Gagala U, Weber-Dabrowska B, Wegrzyn G, Dadlez M (2014) The first step to bacteriophage therapy: how to choose the correct phage. In: Borysowski J (ed) Phage therapy. Current research and applications. Caister Academic Press, Norfolk, pp 23-67

54. Blaisdell BE, Campbell AM, Karlin S (1996) Similarities and dissimilarities of phage genomes. Proc Natl Acad Sci USA 93:5854-5859

55. Edwards RA, McNair K, Faust K, Raes J, Dutilh BE (2016) Computational approaches to predict bacteriophage-host relationships. FEMS Microbiol Rev 40:258-272

56. Lobocka M, Hejnowicz MS, Dabrowski K, Gozdek A, Kosakowski J, Witkowska M, Ulatowska MI, Weber-Dabrowska B, Kwiatek M, Parasion S, Gawor J, Kosowska H, Glowacka A (2012) Genomics of staphylococcal Twort-like phages-potential therapeutics of the post-antibiotic era. Adv Virus Res 83:143-216

57. Rohde C, Resch G, Pirnay JP, Blasdel BG, Debarbieux L, Gelman D, Gorski A, Hazan R, Huys I, Kakabadze E, Lobocka M, Maestri A, Almeida GMF, Makalatia K, Malik DJ, Maslanova I, Merabishvili M, Pantucek R, Rose T, Stverakova D, Van RH, Verbeken G, Chanishvili N (2018) Expert opinion on three phage therapy related topics: bacterial phage resistance, phage training and prophages in bacterial production strains. Viruses 10:178 
58. Kruger DH, Schroeder C (1981) Bacteriophage T3 and bacteriophage T7 virus-host cell interactions. Microbiol Rev 45:9-51

59. Ross A, Ward S, Hyman P (2016) More is better: selecting for broad host range bacteriophages. Front Microbiol 7:1352

60. Chan BK, Abedon ST, Loc-Carrillo C (2013) Phage cocktails and the future of phage therapy. Future Microbiol 8:769-783

61. Chan BK, Sistrom M, Wertz JE, Kortright KE, Narayan D, Turner PE (2016) Phage selection restores antibiotic sensitivity in MDR Pseudomonas aeruginosa. Sci Rep 6:26717

62. Foster TJ (2005) Immune evasion by staphylococci. Nat Rev Microbiol 3:948-958

63. Clokie MRJ (2018) Bacterial defence molecules target viral DNA. Nature 564:199-200

64. Bickle TA, Kruger DH (1993) Biology of DNA restriction. Microbiol Rev 57:434-450

65. Cornelissen A, Lavigne R, Moineau S (2014) Fighting bacteriophage infection: mechanisms of bacterial resistance. In: Borysowski J, Międzybrodzki R, Górski A (eds) Phage Therapy: Current Research and Applications. Caister Academic Press, Norfolk, pp 101-139

66. Samson JE, Magadan AH, Sabri M, Moineau S (2013) Revenge of the phages: defeating bacterial defences. Nat Rev Microbiol 11:675-687

67. Doron S, Melamed S, Ofir G, Leavitt A, Lopatina A, Keren M, Amitai G, Sorek R (2018) Systematic discovery of antiphage defense systems in the microbial pangenome. Science 359:eaar4120

68. Hagens S, Blasi U (2003) Genetically modified filamentous phage as bactericidal agents: a pilot study. Lett Appl Microbiol $37: 318-323$

69. Hagens S, Habel A, Ahsen U, Gabain A, Blasi U (2004) Therapy of experimental pseudomonas infections with a nonreplicating genetically modified phage. Antimicrob Agents Chemother 48:3817-3822

70. Matsuda T, Freeman TA, Hilbert DW, Duff M, Fuortes M, Stapleton PP, Daly JM (2005) Lysis-deficient bacteriophage therapy decreases endotoxin and inflammatory mediator release and improves survival in a murine peritonitis model. Surgery 137:639-646

71. Paul VD, Sundarrajan S, Rajagopalan SS, Hariharan S, Kempashanaiah N, Padmanabhan S, Sriram B, Ramachandran J (2011) Lysis-deficient phages as novel therapeutic agents for controlling bacterial infection. BMC Microbiol 11:195

72. Oliveira H, Sao-Jose C, Azeredo J (2018) Phage-derived peptidoglycan degrading enzymes: challenges and future prospects for in vivo therapy. Viruses 10:292

73. Cornelissen A, Ceyssens PJ, T'Syen J, Van PH, Noben JP, Shaburova OV, Krylov VN, Volckaert G, Lavigne R (2011) The T7-related Pseudomonas putida phage phi15 displays virionassociated biofilm degradation properties. PLoS ONE 6:e18597

74. Chan BK, Abedon ST (2015) Bacteriophages and their enzymes in biofilm control. Curr Pharm Des 21:85-99

75. Abedon ST (2015) Ecology of anti-biofilm agents I: antibiotics versus bacteriophages. Pharmaceuticals (Basel) 8:525-558

76. Abedon ST (2015) Ecology of anti-biofilm agents II: bacteriophage exploitation and biocontrol of biofilm bacteria. Pharmaceuticals (Basel) 8:559-589

77. Ryan EM, Gorman SP, Donnelly RF, Gilmore BF (2011) Recent advances in bacteriophage therapy: how delivery routes, formulation, concentration and timing influence the success of phage therapy. J Pharm Pharmacol 63:1253-1264

78. Beloin C, Renard S, Ghigo JM, Lebeaux D (2014) Novel approaches to combat bacterial biofilms. Curr Opin Pharmacol 18:61-68

79. Pires DP, Melo L, Vilas BD, Sillankorva S, Azeredo J (2017) Phage therapy as an alternative or complementary strategy to prevent and control biofilm-related infections. Curr Opin Microbiol 39:48-56

80. Bjarnsholt T, Alhede M, Alhede M, Eickhardt-Sorensen SR, Moser C, Kuhl M, Jensen PO, Hoiby N (2013) The in vivo biofilm. Trends Microbiol 21:466-474

81. Sillankorva S, Azeredo J (2014) The use of bacteriophages and bacteriophage-derived enzymes for clinically relevant biofilm control. In: Borysowski J (ed) Phage therapy. Current research and applications. Caister Academic Press, Norfolk, pp 309-329

82. da Silva JL, Piuri M, Broussard G, Marinelli LJ, Bastos GM, Hirata RD, Hatfull GF, Hirata MH (2013) Application of BRED technology to construct recombinant D29 reporter phage expressing EGFP. FEMS Microbiol Lett 344:166-172

83. Marinelli LJ, Piuri M, Swigonova Z, Balachandran A, Oldfield LM, van Kessel JC, Hatfull GF (2008) BRED: a simple and powerful tool for constructing mutant and recombinant bacteriophage genomes. PLoS ONE 3:e3957

84. Marinelli LJ, Hatfull GF, Piuri M (2012) Recombineering: a powerful tool for modification of bacteriophage genomes. Bacteriophage 2:5-14

85. Feher T, Karcagi I, Blattner FR, Posfai G (2012) Bacteriophage recombineering in the lytic state using the lambda red recombinases. Microb Biotechnol 5:466-476

86. Citorik RJ, Mimee M, Lu TK (2014) Sequence-specific antimicrobials using efficiently delivered RNA-guided nucleases. Nat Biotechnol 32:1141-1145

87. Bikard D, Euler CW, Jiang W, Nussenzweig PM, Goldberg GW, Duportet X, Fischetti VA, Marraffini LA (2014) Exploiting CRISPR-Cas nucleases to produce sequence-specific antimicrobials. Nat Biotechnol 32:1146-1150

88. Kiro R, Shitrit D, Qimron U (2014) Efficient engineering of a bacteriophage genome using the type I-E CRISPR-Cas system. RNA Biol 11:42-44

89. Yosef I, Manor M, Kiro R, Qimron U (2015) Temperate and lytic bacteriophages programmed to sensitize and kill antibiotic-resistant bacteria. Proc Natl Acad Sci USA 112:7267-7272

90. Martel B, Moineau S (2014) CRISPR-Cas: an efficient tool for genome engineering of virulent bacteriophages. Nucleic Acids Res 42:9504-9513

91. Ando H, Lemire S, Pires DP, Lu TK (2015) Engineering modular viral scaffolds for targeted bacterial population editing. Cell Syst 1:187-196

92. Nobrega FL, Costa AR, Kluskens LD, Azeredo J (2015) Revisiting phage therapy: new applications for old resources. Trends Microbiol 23:185-191

93. Manoharadas S, Blasi U (2014) Genetically engineered phage as antimicrobials and biodetectors. In: Borysowski J (ed) Phage therapy. Current research and applications. Caister Academic Press, Norfolk, pp 343-355

94. Pires DP, Cleto S, Sillankorva S, Azeredo J, Lu TK (2016) Genetically engineered phages: a review of advances over the last decade. Microbiol Mol Biol Rev 80:523-543

95. Barbu EM, Cady KC, Hubby B (2016) Phage therapy in the era of synthetic biology. Cold Spring Harb Perspect Biol 8:a023879

96. Dedrick RM, Guerrero-Bustamante CA, Garlena RA, Russell DA, Ford K, Harris K, Gilmour KC, Soothill J, Jacobs-Sera D, Schooley RT, Hatfull GF, Spencer H (2019) Engineered bacteriophages for treatment of a patient with a disseminated drugresistant Mycobacterium abscessus. Nat Med 25:730-733

97. Scholl D, Adhya S, Merril C (2005) Escherichia coli K1's capsule is a barrier to bacteriophage T7. Appl Environ Microbiol 71:4872-4874

98. Lu TK, Collins JJ (2007) Dispersing biofilms with engineered enzymatic bacteriophage. Proc Natl Acad Sci USA 104:11197-11202 
99. Lu TK, Collins JJ (2009) Engineered bacteriophage targeting gene networks as adjuvants for antibiotic therapy. Proc Natl Acad Sci USA 106:4629-4634

100. Pei R, Lamas-Samanamud GR (2014) Inhibition of biofilm formation by $\mathrm{T} 7$ bacteriophages producing quorum-quenching enzymes. Appl Environ Microbiol 80:5340-5348

101. Edgar R, Friedman N, Molshanski-Mor S, Qimron U (2012) Reversing bacterial resistance to antibiotics by phage-mediated delivery of dominant sensitive genes. Appl Environ Microbiol 78:744-751

102. Westwater C, Kasman LM, Schofield DA, Werner PA, Dolan JW, Schmidt MG, Norris JS (2003) Use of genetically engineered phage to deliver antimicrobial agents to bacteria: an alternative therapy for treatment of bacterial infections. Antimicrob Agents Chemother 47:1301-1307

103. Bhattarai SR, Yoo SY, Lee SW, Dean D (2012) Engineered phage-based therapeutic materials inhibit Chlamydia trachomatis intracellular infection. Biomaterials 33:5166-5174

104. Mueller PF, Roemer W (2018) Phage therapy against intracellular bacterial pathogens: developing new liposomal delivery strategies [abstract]. Arch Int Soc Microb 5:89

105. Marzari R, Sblattero D, Righi M, Bradbury A (1997) Extending filamentous phage host range by the grafting of a heterologous receptor binding domain. Gene 185:27-33

106. Heilpern AJ, Waldor MK (2003) pIIICTX, a predicted CTXphi minor coat protein, can expand the host range of coliphage fd to include Vibrio cholerae. J Bacteriol 185:1037-1044

107. Yoichi M, Abe M, Miyanaga K, Unno H, Tanji Y (2005) Alteration of tail fiber protein gp38 enables T2 phage to infect Escherichia coli O157:H7. J Biotechnol 115:101-107

108. Mahichi F, Synnott AJ, Yamamichi K, Osada T, Tanji Y (2009) Site-specific recombination of T2 phage using IP008 long tail fiber genes provides a targeted method for expanding host range while retaining lytic activity. FEMS Microbiol Lett 295:211-217

109. Lin TY, Lo YH, Tseng PW, Chang SF, Lin YT, Chen TS (2012) A T3 and T7 recombinant phage acquires efficient adsorption and a broader host range. PLoS ONE 7:e30954

110. Chen M, Zhang L, Abdelgader SA, Yu L, Xu J, Yao H, Lu C, Zhang W (2017) Alterations in gp37 expand the host range of a T4-like phage. Appl Environ Microbiol 83:e01576-17

111. Hodyra-Stefaniak K, Miernikiewicz P, Drapala J, Drab M, Jonczyk-Matysiak E, Lecion D, Kazmierczak Z, Beta W, Majewska J, Harhala M, Bubak B, Klopot A, Gorski A, Dabrowska K (2015) Mammalian Host-Versus-Phage immune response determines phage fate in vivo. Sci Rep 5:14802

112. Merril CR, Biswas B, Carlton R, Jensen NC, Creed GJ, Zullo S, Adhya S (1996) Long-circulating bacteriophage as antibacterial agents. Proc Natl Acad Sci USA 93:3188-3192

113. Vitiello CL, Merril CR, Adhya S (2005) An amino acid substitution in a capsid protein enhances phage survival in mouse circulatory system more than a 1000-fold. Virus Res 114:101-103

114. Nam Y, Yang MY, Yu JH (2018) Efficient in vivo phage therapy via immunological cloaking [abstract]. Arch Int Soc Microb 5:23

115. Murphy J, Mahony J, Ainsworth S, Nauta A (2013) van SD: Bacteriophage orphan DNA methyltransferases: insights from their bacterial origin, function, and occurrence. Appl Environ Microbiol 79:7547-7555

116. Loessner MJ, Rees CE, Stewart GS, Scherer S (1996) Construction of luciferase reporter bacteriophage A511:luxAB for rapid and sensitive detection of viable Listeria cells. Appl Environ Microbiol 62:1133-1140

117. Sarkis GJ, Jacobs WR Jr, Hatfull GF (1995) L5 luciferase reporter mycobacteriophages: a sensitive tool for the detection and assay of live mycobacteria. Mol Microbiol 15:1055-1067

118. Oda M, Morita M, Unno H, Tanji Y (2004) Rapid detection of Escherichia coli O157:H7 by using green fluorescent protein-labeled PP01 bacteriophage. Appl Environ Microbiol 70:527-534

119. Edgar R, McKinstry M, Hwang J, Oppenheim AB, Fekete RA, Giulian G, Merril C, Nagashima K, Adhya S (2006) High-sensitivity bacterial detection using biotin-tagged phage and quantumdot nanocomplexes. Proc Natl Acad Sci USA 103:4841-4845

120. Namura M, Hijikata T, Miyanaga K, Tanji Y (2008) Detection of Escherichia coli with fluorescent labeled phages that have a broad host range to E. coli in sewage water. Biotechnol Prog $24: 481-486$

121. Piuri M, Jacobs WR Jr, Hatfull GF (2009) Fluoromycobacteriophages for rapid, specific, and sensitive antibiotic susceptibility testing of Mycobacterium tuberculosis. PLoS ONE 4:e4870

122. Schofield DA, Molineux IJ, Westwater C (2011) 'Bioluminescent' reporter phage for the detection of Category A bacterial pathogens. J Vis Exp 53:e2740

123. Nguyen C, Makkar R, Sharp NJ, Page MA, Molineux IJ, Schofield DA (2017) Detection of Bacillus anthracis spores from environmental water using bioluminescent reporter phage. J Appl Microbiol 123:1184-1193

124. Sharp NJ, Vandamm JP, Molineux IJ, Schofield DA (2015) Rapid detection of Bacillus anthracis in complex food matrices using phage-mediated bioluminescence. J Food Prot 78:963-968

125. Yacoby I, Bar H, Benhar I (2007) Targeted drug-carrying bacteriophages as antibacterial nanomedicines. Antimicrob Agents Chemother 51:2156-2163

126. Yacoby I, Shamis M, Bar H, Shabat D, Benhar I (2006) Targeting antibacterial agents by using drug-carrying filamentous bacteriophages. Antimicrob Agents Chemother 50:2087-2097

127. Vaks L, Benhar I (2011) Antibacterial application of engineered bacteriophage nanomedicines: antibody-targeted, chloramphenicol prodrug loaded bacteriophages for inhibiting the growth of Staphylococcus aureus bacteria. Methods Mol Biol 726:187-206

128. Vaks L, Benhar I (2011) In vivo characteristics of targeted drugcarrying filamentous bacteriophage nanomedicines. J Nanobiotechnology 9:58

129. Atterbury RJ (2009) Bacteriophage biocontrol in animals and meat products. Microb Biotechnol 2:601-612

130. Huber I, Potapova K, Kuhn A, Schmidt H, Hinrichs J, Rohde C, Beyer W (2018) 1st german phage symposium-conference report. Viruses 10:158

131. Briers Y, Walmagh M, Van P (2014) V, Cornelissen A, Cenens W, Aertsen A, Oliveira H, Azeredo J, Verween G, Pirnay JP, Miller S, Volckaert G, Lavigne R: Engineered endolysin-based "Artilysins" to combat multidrug-resistant gram-negative pathogens. MBio 5:e01379-14

132. Lood R, Winer BY, Pelzek AJ, Diez-Martinez R, Thandar M, Euler CW, Schuch R, Fischetti VA (2015) Novel phage lysin capable of killing the multidrug-resistant gram-negative bacterium Acinetobacter baumannii in a mouse bacteremia model. Antimicrob Agents Chemother 59:1983-1991

133. Pires DP, Oliveira H, Melo LD, Sillankorva S, Azeredo J (2016) Bacteriophage-encoded depolymerases: their diversity and biotechnological applications. Appl Microbiol Biotechnol 100:2141-2151

134. Gutierrez D, Fernandez L, Rodriguez A, Garcia P (2018) Are phage lytic proteins the secret weapon to kill Staphylococcus aureus? MBio 9:e01923-17

135. Maciejewska B, Olszak T, Drulis-Kawa Z (2018) Applications of bacteriophages versus phage enzymes to combat and cure bacterial infections: an ambitious and also a realistic application? Appl Microbiol Biotechnol 102:2563-2581

136. Latka A, Maciejewska B, Majkowska-Skrobek G, Briers Y, Drulis-Kawa Z (2017) Bacteriophage-encoded virion-associated enzymes to overcome the carbohydrate barriers during the infection process. Appl Microbiol Biotechnol 101:3103-3119 
137. Drulis-Kawa Z, Majkowska-Skrobek G, Maciejewska B (2015) Bacteriophages and phage-derived proteins-application approaches. Curr Med Chem 22:1757-1773

138. Pastagia M, Schuch R, Fischetti VA, Huang DB (2013) Lysins: the arrival of pathogen-directed anti-infectives. J Med Microbiol 62:1506-1516

139. Yang H, Yu J, Wei H (2014) Engineered bacteriophage lysins as novel anti-infectives. Front Microbiol 5:542

140. Fischetti VA (2010) Bacteriophage endolysins: a novel anti-infective to control Gram-positive pathogens. Int J Med Microbiol 300:357-362

141. Cornelissen A, Ceyssens PJ, Krylov VN, Noben JP, Volckaert G, Lavigne R (2012) Identification of EPS-degrading activity within the tail spikes of the novel Pseudomonas putida phage AF. Virology 434:251-256

142. Lin H, Paff ML, Molineux IJ, Bull JJ (2017) Therapeutic application of phage capsule depolymerases against K1, K5, and K30 capsulated E. coli in Mice. Front Microbiol 8:2257

143. Majkowska-Skrobek G, Latka A, Berisio R, Squeglia F, Maciejewska B, Briers Y, Drulis-Kawa Z (2018) Phage-borne depolymerases decrease Klebsiella pneumoniae resistance to innate defense mechanisms. Front Microbiol 9:2517

144. Fischetti VA (2018) Development of phage lysins as novel therapeutics: a historical perspective. Viruses 10:310

145. Saier MH Jr, Reddy BL (2015) Holins in bacteria, eukaryotes, and archaea: multifunctional xenologues with potential biotechnological and biomedical applications. J Bacteriol 197:7-17

146. Gerstmans H, Rodriguez-Rubio L, Lavigne R, Briers Y (2016) From endolysins to Artilysin(R)s: novel enzyme-based approaches to kill drug-resistant bacteria. Biochem Soc Trans 44:123-128

147. Rodriguez-Rubio L, Chang WL, Gutierrez D, Lavigne R, Martinez B, Rodriguez A, Govers SK, Aertsen A, Hirl C, Biebl M, Briers Y, Garcia P (2016) 'Artilysation' of endolysin lambdaSa2lys strongly improves its enzymatic and antibacterial activity against streptococci. Sci Rep 6:35382

148. Defraine V, Schuermans J, Grymonprez B, Govers SK, Aertsen A, Fauvart M, Michiels J, Lavigne R, Briers Y (2016) Efficacy of artilysin art-175 against resistant and persistent Acinetobacter baumannii. Antimicrob Agents Chemother 60:3480-3488

149. Miller S (2017) Artilysin ${ }^{\circledR}$ : Targeted elimination of bacterial pathogens resulting in a faster wound healing. [abstract]. 22nd Biennial Evergreen International Phage Meeting, The Evergreen State College, Olympia, p 35.

150. Shi Y, Li N, Yan Y, Wang H, Li Y, Lu C, Sun J (2012) Combined antibacterial activity of phage lytic proteins holin and lysin from Streptococcus suis bacteriophage SMP. Curr Microbiol 65:28-34

151. Olsen NMC, Thiran E, Hasler T, Vanzieleghem T, Belibasakis GN, Mahillon J, Loessner MJ, Schmelcher M (2018) Synergistic removal of static and dynamic Staphylococcus aureus biofilms by combined treatment with a bacteriophage endolysin and a polysaccharide depolymerase. Viruses 10:438

152. Scholl D (2017) Phage Tail-Like Bacteriocins. Annu Rev Virol 4:453-467

153. Wang Q, Euler CW, Delaune A, Fischetti VA (2015) Using a novel lysin to help control clostridium difficile infections. Antimicrob Agents Chemother 59:7447-7457

154. Smith MK, Draper L, Hayes C, Connolly O, Dalmasso M, Ross RP, Hill C (2017) Phages targeting Streptococci of the oral cavity. [abstract]. 22nd Biennial Evergreen International Phage Meeting, The Evergreen State College, Olympia, p 183.

155. Maervoet VET, Briers Y (2017) Synthetic biology of modular proteins. Bioengineered 8:196-202

156. Diez-Martinez R, De Paz HD, Garcia-Fernandez E, Bustamante N, Euler CW, Fischetti VA, Menendez M, Garcia P (2015) A novel chimeric phage lysin with high in vitro and in vivo bactericidal activity against Streptococcus pneumoniae. J Antimicrob Chemother 70:1763-1773

157. Wang Z, Kong L, Liu Y, Fu Q, Cui Z, Wang J, Ma J, Wang H, Yan Y, Sun J (2018) A phage lysin fused to a cell-penetrating peptide kills intracellular methicillin-resistant Staphylococcus aureus in keratinocytes and has potential as a treatment for skin infections in mice. Appl Environ Microbiol 84:e00380-18

158. Sobieraj A, Seijsing J, Zinsli L, Meile S, Eichenseher F, Keller N, Huemer M, Zinkernagel AS, Loessner MJ, Schmelcher M (2018) Engineering of phage endolysin-based proteins for improved serum circulation half-life and efficient killing of Staphylococcus aureus [abstract]. Conference on Viruses of Microbes, Wroclaw, p 54.

159. Fischetti VA (2006) Using phage lytic enzymes to control pathogenic bacteria. BMC Oral Health 6(Suppl 1):S16

160. Loeffler JM, Djurkovic S, Fischetti VA (2003) Phage lytic enzyme Cpl-1 as a novel antimicrobial for pneumococcal bacteremia. Infect Immun 71:6199-6204

161. Schuch R, Fischetti VA, Nelson DC (2009) A genetic screen to identify bacteriophage lysins. Methods Mol Biol 502:307-319

162. Schmitz JE, Schuch R, Fischetti VA (2010) Identifying active phage lysins through functional viral metagenomics. Appl Environ Microbiol 76:7181-7187

Publisher's Note Springer Nature remains neutral with regard to jurisdictional claims in published maps and institutional affiliations. 